\title{
Study on the Power and Survival Philosophy in Kafka`s "Castle"
}

\author{
Yang Yang \\ School of Foreign Languages, Hebei University of Technology, Tianjin, 300401, China
}

\author{
Keywords: Kafka. Castle. Power mentality. Survival philosophy
}

\begin{abstract}
Kafka`s Castle is a master piece with extraordinary charm, it has shown a special world and lead the reader to view the social phenomenon and the different relationship between different people.the paper mainly analyzed the power mentality and survival philosophy.
\end{abstract}

\section{Introduction}

Franz Kafka is a Austral writer with special thinking and extraordinary talent, it represent work "Castle"has reflected the small figures" living condition in the capitalism country to the global readers. The castle is a microcosm of tyranny, it is also a symbol of power. The officers in the castle are corruptive and incompetent, the people living under their regime are also depressed and confused, the destiny and living condition of the small figures is unspeakable heavy. Once people get next to the ordinary people in the castle, the sense of heaviness will stay in the heart for a very long time, which makes the modern people sympathize the depressed and hard-to-rescue living condition of the small figures.

\section{Analysis of the power mentality in Kafka`s “Castle”}

The first paragraph of the novel has clearly shown the population distribution and power structure.Geographically, the castle is located in the mountain, which is aeriality and unpredictable,so it is kind of mysterious; the village is located at the foot of the mountain, it is covered by the accumulated snow, it always suffer silently from the icy snow. As to the social status, the people living the castle is the manager, i.e the ruler, the people in the village are those being managed. The castle is powerful, while the village has no place at all. $\mathrm{K}$ is a foreigner, his sudden appear formed the third power, thus disturbed the existed order between the castle and village. The castle and village is a relatively independent group, for the $\mathrm{K}$,the two sides were integrated as one closed structure. $\mathrm{K}$ is a loner thrown into this world by the narrator of the novel. During the six days since the K entering into the world till the stoppage of the novel, through the experience and observation of $\mathrm{K}$, the author has shown a strange and familiar new world to the readers. Everything in the world has shown the effects brought by the power mentality and absolute power in all respects.

For $\mathrm{K}$, the castle is far away to reach. It is impossible for $\mathrm{K}$ to go to the castle no matter how hard he tries. He can only feel the power of the castle, so this create some imageries about the castle. The power of the castle is reflected by the officers, which is represented by Klum. According to the description in the novel. Klum is someone who have religious authority , monarchical power and patriarchy all in one. As for his outlook, the author didn `t say anything, nobody ever saw him, but Olga said that "everyone is familiar with his face." in people`s imagination, Klum`s figure changes a lot. The reason for that is because his figure changed along with the emotions and how hopeful they are. The villager worship him as a god, nobody dare meet the god. It is ask for the moon for K to see Klum, for example, the hotel-owner at the bridge head was scared to shake all over her body after knowing K wanted to meet him, and she tried her best to persuade him to give up. The villagers are all afraid of Klum very much, give him the divine dignity, even being called to the name by him would be an horner.

This invisible, untouchable and immanence power rules the village. This is not only abstract, but also concretization. His name itself is a very abstract power symbol, as long as it is mentioned, the villagers would be scared. Frieda drove the slaved into the house ring in Klum`s name. Moms asked 
$\mathrm{K}$ to answer his questions in Klum`s name, this can be regarded the same as in the name of Jesus Christ. The power of Klum spreads everywhere. When K steal his lover Frieda, he did not even make a sound, just let them make out on the floor of the hotel bar which is full of beer retention and garbage. Because they are way too devoted, they didn 't even notice that two assistants sent from the castle was watching them closely, this even makes Frieda think that this make out scene with $\mathrm{K}$ is arranged by Klum. The real power even ruled all aspects of the villager`s life. The villagers said that "Nobody can hide anything in front of Klum.”, which apparently indicated one of the features of Klum `s power, which is he knows everything just like the god.

Although the power comes from the castle, and from Klum, but the power is anonymous and non-personal after all. Amelie was punished for having torn apart the calling letter from the castle. Although there is no penalty from the castle, but all her families was sucked into a never-ending disaster, when Amelie`s father going everywhere to rebuild her daughter`s reputation. There is no government officer care about this, because there is no charge, and no one would accuse them,let alone putting on record. His father can on longer be a firefighter, although he is the best shoemaker in the village, but there is no business any more, even the whole families suffer from despise, everybody avoid them just like escaping the plague.Olga tell $\mathrm{K}$ that it is very difficult to change people`s despite towards them, because everything is related to the castle, but no one in the castle would take care of this. So , anonymous power come into real effect.

We can say that the power here can be found everywhere, what the power represent is also omniscient, the anonymous power can function by itself, and take effect by religious activities. The power allows no doubt, the officers representing by the power would always be right. This is the truth of the castle`s power.

\section{The analysis of the survival philosophy in the Kafka`s "Castle”}

\subsection{The pursuit of goal is unrealistic}

The plot of the Castle is not very complicated, the whole stroy can be summarized like this: K did a hopeless fight for living in the castle and gaining the identity recognition there. The novel set the castle as the first object going into the reader`s heart, he let the reader get the first impression through K`eyes. The grand castle is high up above, which makes people feel distanced. This position makes people feel that it is above $\mathrm{K}$ and above the village. But $\mathrm{K}$ admires it. At this moment, the castle is very mysterious, holy and scared in K`s perspective. The first impression of the castle then deeply implemented in K`s mind. This is a very good foundation for the later story that $\mathrm{K}$ spent his whole life struggling to go the castle without success. Castle, with its peculiar hazy, mysterious image, is a symbol of the power and domination. It is always majesty, huge and mysterious at the same time, just like the empty and nihility illusion, while as a occasional interlopers, no matter how hard $\mathrm{K}$ tries, $\mathrm{K}$ will always be a useless people for the castle.

In the first letter of Barnabas, $\mathrm{K}$ has already realized that it would be very difficult to go to the castle and gain the recognition there. At its surrounding area, within the regime of the castle, there are also many different forces oppose him at the same time, which kept him in the castle. And make him lose the freedom of thoughts and action, and this scene also filled K`s mind with fear all of sudden. Because what he is afraid of is this disappointing environment and the force of habit, he has to fight against it. Sometime he even worries that this might be a never-ending road.K always feel himself infinitely close to the castle but infinitely far away from the castle, but he still pursue his goal stubbornly with determination. He is overloaded on the road to his goal. At the same time,he did a lot of things that he may not do before coming to the castle. He tried his best to get next to the officer in the castle, he took away castle office Klum`s lover Frieda, he did all he can to please Barnabas` family. Which is to say, $\mathrm{K}$ has tried desperately to gain the recognition of the castle, but what is the result?

Even the day that he pass away, $\mathrm{K}$ is still a land surveyor without any specific identity. $\mathrm{K}$ use his life as a bookmaker in a fight that he is doomed to lose, this is a fight that an individual against the strong and tight world which is also absurd and corruptive. K spent his tough and heavy life on the 
goal which is impossible to achieve. We say it is impossible because the castle has controlled one`s entire life, and decided the people`s behavior. Because they were controlled by the castle, they lose their precious freedom, so although they have their thoughts and behavior, but it is all based on an impossible goal.such a humble man like $\mathrm{K}$, he was placed in an awkward position that pursuing a goal that will never reach. The meaning and value of his existence is tore into pieces, and makes people can`t help to sympathize his living conditions.

\subsection{The love under the control of the castle have uncertain factors}

In the castle which is full of autocracy, corruption and absurdity, love inevitably effected by the environment and lose its purity and innocence nature.Frieda is quite common outwardly, but she has a quite superior vision, which is quite unusual, the reason why K observes Frieda carefully is because the superiority in her eyes,not because of love. Actually, $\mathrm{K}$ `s love for Frieda is simply using in the first place, the reason why she is so important is because she`s connection to the castle. K wants to use her to rescue himself, K`s interested-oriented love for Frieda makes people feel sad. From K`s interested-oriented love for Frieda, we can see that their love has some uncertain factors from the beginning stage.

In the autocratic and wild world of castle, people`s feeling for each other would definitely be strongly effected by the dirty environment, $\mathrm{K}$ gets close to Frieda not because of love.but how does Frieda view this relationship? As a bar girl, she also is the lover of castle officer Klum. However, after having met K, she became part of K`s love life. Actually, she has always wanted to choose her own life, and has much desire for the pure and noble love, she know the pressure and effect that the castle has on the people living in it, the love that she wants dose not exist in the world at all, this makes her feel deeply insecure and distrust about love.she can`t give up Klum, although she does have refused him in front of $\mathrm{K}$ forcefully, but she still wants him badly inside, because Klum can give her something that $\mathrm{K}$ can 't.But living under the control of the castle, those things are essential to Frieda. She once tired to love K, but her love for him have certain degree of anxiety and uncertainty, Frieda knows that K`s goal is the castle, and that is everything in his life. So, Frieda could only view her relationship with $\mathrm{K}$ with fear and anxiety, she always feels this love is floating, because from the perspective of Frieda, her love affair with K lack of security, and impurity as well.

For $\mathrm{K}$, he can never give up his goal to go to castle and gain identity recognition so he is not willing to falling in love with Frieda. On the other hand, Frieda is also very reluctant to negotiate with Klum for K`s goal,and that is because she knows how to live a good life in the castle. Because the castle has a very deep control over people`s mentality, K and Frieda could only live under the castle`s control for their own interests

\section{Conclusion}

K could never make his dream come true, his confusing and troublesome love affair with Frieda, painstaking self-rescuing of Amelia`s families, these all filled with unspeakable pain and heaviness under the Kafka`s description. No matter what kind of attitude they adopt towards life, they would only end up with failure, which makes people sympathize people`s effort for achieving their goal in the castle. Based on the living condition of the ordinary people in the real world in the Castle, Kafka carved the mark of heaviness on them, which makes the readers had a deeper understanding about its power philosophy and survive philosophy

\section{References}

[1] Can Xue: The Castle`s soul: Understand Kafka. Shanghai:Shanghai literature and Art Publishing House, 1999

[2] Li Xiaolin: Analysis of the Kafka`s Castle from Foucault's "micro power" perspective. Journal of Zaozhuang University, 2006 (1).

[3] Li Zhanqi: Kafka`s Castle`s multiple explanation mystery. Journal of Hebei Union University (social science edition.), 2010 (6) 
[4] Liu Donglin: Discover the Zen Buddhism in the Western Culture---take Kafka`s Castle as an example. Literature and Art Forum, 2011(12)

[5] Zhao Nan: The artistic charm of narrative time---analysis of the Kafka`s castle. Appreciation, $2013(9)$ 